Controlling the State 



\section{Controlling the State}

Constitutionalism from

Ancient Athens to Today

Scott Gordon

Harvard University Press

Cambridge, Massachusetts, and London, England 
Copyright (C) 1999 by the President and Fellows of Harvard College All rights reserved

Printed in the United States of America

This book has been digitally reprinted. The content remains identical to that of previous printings.

First Harvard University Press paperback edition, 2002

\section{Library of Congress Cataloging-in-Publication Data}

Gordon, Scott, 1924-

Controlling the state : constitutionalism from ancient Athens to today / Scott Gordon.

p. $\mathrm{cm}$.

Includes bibliographical references and index.

ISBN 0-674-16987-5 (cloth)

ISBN 0-674-00977-0 (pbk.)

1. Separation of powers. 2. Authority. 3. Liberty.

4. Constitutional history. I. Title.

JF229.G67 1999

$321.8^{\prime} 01-\mathrm{dc} 21$ 
In all government there is a perpetual intestine struggle, open or secret, between Authority and Liberty, and neither of them can ever absolutely prevail in the contest. A great sacrifice of liberty must necessarily be made in every government; yet even the authority which confines liberty can never, and perhaps ought never, in any constitution to become quite entire and uncontrollable ... It must be owned that liberty is the perfection of civil society, but still authority must be acknowledged essential to its very existence.

-DAVID HUME 
